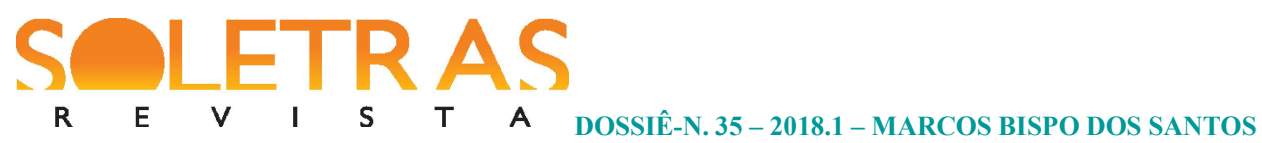

\title{
Epistemologia da prática e desenvolvimento profissional no Mestrado Profissional em Letras
}

Marcos Bispo dos Santos ${ }^{1}$

\begin{abstract}
Resumo: O Programa de Mestrado Profissional em Letras (Profletras) teve início no ano de 2013, como resultado do esforço de expansão dos mestrados profissionais, modalidade de pós-graduação já prevista para oferta no Brasil desde 1965, conforme consta do Parecer $n^{\circ}$ 977/65 do Conselho Federal de Educação. Neste texto, questiona-se a adequação da pesquisa aplicada baseada na transposição de teorias para promover o desenvolvimento profissional dos docentes, de acordo com os objetivos do Programa. Partindo da proposta de formação profissional fundada na epistemologia da prática elaborada por Schön (2000) e desenvolvida por diversos outros autores como García (1999), Perrenoud (2008), Paquay et al. (2012), Tardif (2011) dentre outros, apresento um modelo de formação profissional do professor reflexivo, entendido como mais coerente com os objetivos do Programa.
\end{abstract}

Palavras-chave: Mestrado Profissional em Letras. Formação de Professores. Desenvolvimento profissional. Professor-pesquisador.

\section{Introdução}

A oferta de cursos de Mestrado Profissional (MP), na pós-graduação brasileira, é fenômeno recente, apesar de já estar prevista no Parecer nº 977/65 do então Conselho Federal de Educação. A hipervalorização do viés acadêmico, reforçada, sobretudo, pela proeminência da concepção de pesquisa orientada para a produção e não para aplicação de conhecimentos, contribuiu de maneira decisiva para que praticamente não houvesse oferta de cursos de MP nas universidades brasileiras. Essa concepção é responsável, dentre outras coisas, pelo lugar de inferioridade que as ciências aplicadas ocupam em relação às ciências que produzem conhecimento de base, na hierarquia acadêmica. Tal relação se caracteriza ainda pelo entendimento de que às ciências aplicadas cabe apenas a utilização de conhecimentos produzidos alhures com a finalidade de responder a problemas práticos em contextos específicos.

\footnotetext{
${ }^{1}$ Doutor em Letras e Linguística pelo Programa de Pós-Graduação em Letras e Linguística da Universidade Federal da Bahia. Professor Adjunto na Universidade do Estado da Bahia (UNEB), Colegiado de Letras - Língua Portuguesa e Literaturas; Professor do Mestrado Profissional em Letras (Profletras) da Universidade do Estado da Bahia (UNEB), Bahia, Salvador, Brasil. E-mail: mabispo@uneb.br
} 


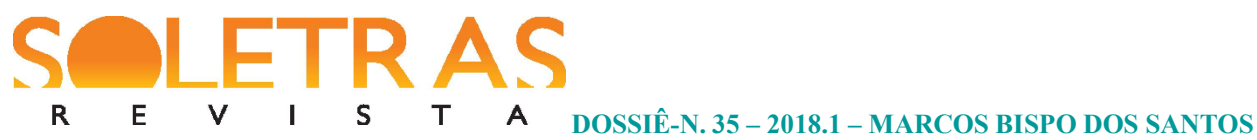

A regulamentação do MP em 1998, não obstante tenha the garantido legitimidade acadêmica, no sentido de que tal modalidade de pós-graduação stricto sensu, de fato, adquiriu status institucional, ainda reproduz a hierarquia entre ciência fundamental e aplicada. A Portaria Normativa $\mathrm{n}^{\circ} 7$, de 22 de junho de 2009, que dispõe sobre o MP no âmbito da Capes, explicita o entendimento de que a nova modalidade de pós-graduação, diferente da acadêmica, tem a finalidade de capacitar profissionais qualificados para o exercício de práticas profissionais avançadas e transformadoras de procedimentos, visando a atender demandas do mercado de trabalho. O documento, porém, ratifica e reforça o entendimento de que o contexto da prática profissional representa apenas espaço de aplicação e não de produção de conhecimento, conforme se pode ler no Art. $3^{\circ}$ :

O mestrado profissional é definido como modalidade de formação pós-graduada stricto sensu que possibilita:

I - a capacitação de pessoal para a prática profissional avançada e transformadora de procedimentos e processos aplicados, por meio da incorporação do método científico, habilitando o profissional para atuar em atividades técnico-científicas e de inovação;

II - a formação de profissionais qualificados pela apropriação e aplicação do conhecimento embasado no rigor metodológico e nos fundamentos científicos; III - a incorporação e atualização permanentes dos avanços da ciência e das tecnologias, bem como a capacitação para aplicar os mesmos, tendo como foco a gestão, a produção técnico-científica na pesquisa aplicada e a proposição de inovações e aperfeiçoamentos tecnológicos para a solução de problemas específicos.

Neste trabalho, têm-se como objetivos: i) apresentar uma problematização envolvendo a definição dos objetivos do Mestrado Profissional em Letras e sua relação com os princípios dos MP, considerando as especificidades da área de educação. Tal problema pode ser assim formulado: A concepção do trabalho final como prática de pesquisa aplicacionista é uma metodologia de formação que se coaduna com o objetivo de desenvolver as competências profissionais para o ensino de língua portuguesa definidas pelo Profletras? ii) apresentar uma proposta metodológica de desenvolvimento profissional, tendo em vista os objetivos do Profletras. 


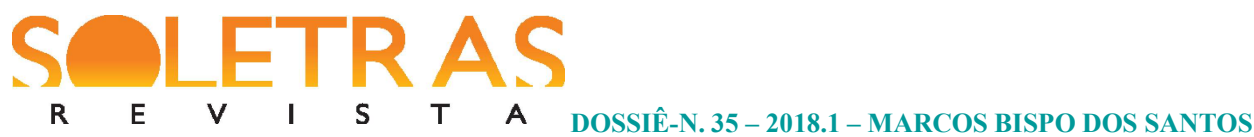

\section{Perspectiva técnica, epistemologia da prática e formação profissional}

Uma das críticas mais relevantes à concepção de formação profissional orientada pela racionalidade técnica foi feita por Schön (2000). A constatação de que a prática profissional é eivada de situações problemáticas e zonas de indefinição que escapam ao domínio das teorias científicas, levou-o a concluir que as escolas profissionais parecem menos capazes de ensinar o que os aspirantes a profissionais mais precisam aprender. Como solução para esse dilema, propõe uma inversão na ordem predominante na estrutura organizacional dos cursos de formação profissional:

[...] em lugar de começar perguntando de que forma podemos fazer melhor uso do conhecimento oriundo da pesquisa, deveríamos partir de um exame cuidadoso do talento artístico, ou seja, da competência através da qual os profissionais realmente dão conta de zonas indeterminadas da prática [...] (SCHÖN, 2000, p. 22).

Tal proposta não nega importância à ciência aplicada ou à técnica baseada em pesquisa, ainda que reconheça suas limitações quanto ao potencial de compreensão do talento artístico próprio de profissionais competentes. Na avaliação de Schön (2000), a construção de uma epistemologia da prática, uma teoria da ação profissional, precisa considerar a relação entre três diferentes tipos de arte: uma arte da sistematização de problemas, uma arte da implementação e uma arte da improvisação - todas necessárias para medir o uso, na prática, da ciência aplicada e da técnica. Assim, tal epistemologia da prática postula que a profissionalização deve-se dar a partir de um ensino prático reflexivo, voltado para ajudar os estudantes a adquirir os tipos de talentos artísticos essenciais para a competência em zonas indeterminadas da prática.

Embora atribua relevo aos conhecimentos técnicos e científicos na formação de professores, o enfoque reflexivo denuncia a ilusão cientificista que propõe transformá-los em pesquisadores amadores. Perrenoud (2002, p. 101) estabelece, de maneira precisa, o alcance das contribuições de uma formação para a pesquisa, na profissionalização docente: 


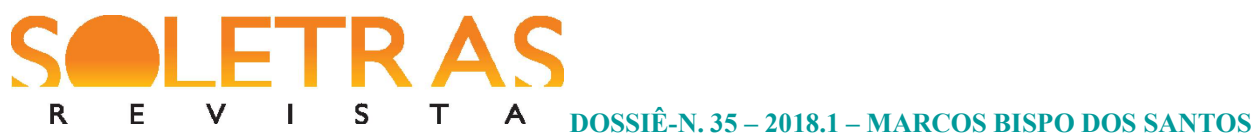

[...] a prática de ensino não é e nunca será uma prática de pesquisa, pois é exercida em condições nas quais a decisão é urgente e o valor do saber é medido mais pela sua eficácia pragmática do que pela coerência teórica ou pelas regras do método, as quais permitiram sua elaboração controlada.

$\mathrm{O}$ que os professores mais podem aprender, em contato com a pesquisa em educação, provém do olhar, das questões que ela suscita, e não tanto dos métodos e das técnicas. É próprio da pesquisa subverter a percepção, revelar o oculto, suspeitar o inconfessável, estabelecer ligações que não saltam aos olhos, reconstruir as coerências sistêmicas sob a aparente desordem. A principal contribuição prática no âmbito da educação é sua teoria ou, mais modestamente, o conjunto dos paradigmas de interpretativos que as ciências humanas propõem acerca dos fatos didáticos e educativos.

Ao contrário do que se evidencia na perspectiva técnica, em que o professor é visto como um tecnólogo habilitado para a aplicação de conhecimentos e técnicas científicas entendidas como suficientes para o desempenho profissional, a demarcação proposta por Perrenoud postula que a principal regulação da prática docente provém da reflexão do próprio profissional, desde que ele seja capaz de propor questões, de aprender a partir da experiência, de inovar, observar, ajustar progressivamente sua ação às reações previsíveis dos outros. Nesse sentido, as teorias das ciências humanas não podem pretender substituir a prática reflexiva do professor em situação. No melhor dos casos, podem fecundá-la, incentivá-la, propor algumas ferramentas, alguns conceitos e hipóteses que reforcem seu poder e legitimidade (SCHÖN, 2000).

Pérez Gómez (1998b) também adverte que o conhecimento acadêmico, teórico, científico ou técnico, só pode ser considerado instrumento dos processos de reflexão quando for integrado significativamente, não em parcelas isoladas da memória semântica, mas nos esquemas de pensamento mais genéricos que o indivíduo ativa ao interpretar a realidade concreta em que vive e sobre a qual atua, e quando organiza sua própria experiência. Isso equivale a dizer que não se trata de um conhecimento puro ou fragmentado que obedece à lógica da pesquisa científica, mas de um conhecimento contaminado pelas contingências que rodeiam e impregnam a própria experiência vital. Essa forma de encarar a relação entre conhecimento teórico e prática profissional impõe que ciência aplicada seja concebida como uma teoria da prática, não a idealizada pelos modelos científicos, mas a que está comprometida com a compreensão da realidade em sua complexidade, portanto, não fragmentada. Daí decorrem duas acepções da 


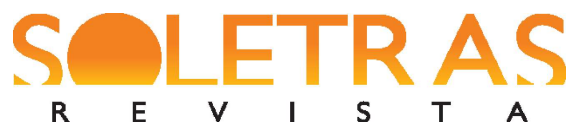

noção de prática: a prática como atividade compreensiva, voltada para a investigação dos conhecimentos subjacentes ao exercício profissional, e a prática como competência técnica efetiva para o exercício da profissão, o saber-fazer propriamente dito. As palavras de Sacristán e Pérez Gómez (1998, p. 10) deixam clara essa diferença, ao mesmo tempo em que apontam os limites das propostas de formação para a prática na segunda acepção:

\begin{abstract}
A prática - a boa e correta prática - não pode ser deduzida diretamente de conhecimentos científicos descontextualizados das ações realizadas em situações reais. Em primeiro lugar, porque a realidade educativa em que os professores/as devem trabalhar não foi criada pela ciência, como acontece com muitas tecnologias modernas. Se acreditássemos que os professores/as podem realizar um ensino "adequado" a partir do conhecimento científico, deveríamos explicarlhes por que sempre se deparam com uma realidade que os impede de realizar esta prática. A profissionalidade do docente, antes de se deduzir simplesmente da ciência, deve assentar-se sobre um bom julgamento ilustrado pelo saber e apoiar-se num senso crítico e ético que seja capaz de apreciar o que convém fazer, o que é possível e como fazê-lo dentro de determinadas circunstâncias.
\end{abstract}

Para elaborar uma epistemologia da prática com o fim de orientar a formação do profissional prático reflexivo, Schön (2000) correlaciona a reflexão com diferentes momentos da atuação profissional e estabelece uma escala que parte do conhecimento tácito, ou saberes da experiência, até a prática reflexiva em sentido amplo. Os conceitos que designam as diferentes fases do ensino reflexivo são os seguintes:

a) Conhecer-na-ação: corresponde ao conhecimento implícito ou tácito, inerente ao talento artístico profissional, fruto da experiência ou de reflexões passadas, consolidado em esquemas semiautomáticos e rotinas. Por se tratar de uma competência que independe da capacidade de descrição ou explicitação de seus pressupostos por parte de quem o aciona, é fundamental, para o ensino reflexivo, que o conhecer-na-ação seja descrito. Quando isso acontece, o conhecer se converte em conhecimento-na-ação.

b) A reflexão na ação: o conhecer-na-ação permite ao prático acionar esquemas de ação que recobrem as situações previsíveis. Contudo, a prática educativa tem como uma de suas características a imprevisibilidade, demandando a necessidade de tomadas de decisões 


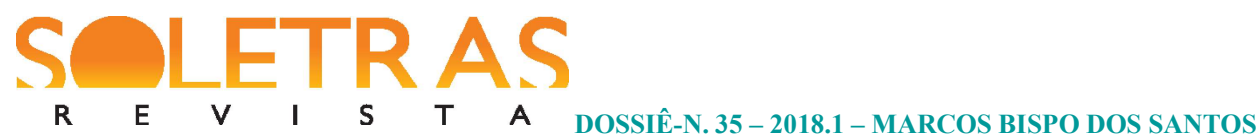

repentinas e, por isso, nem sempre fundadas em certezas advindas de algum procedimento de experimentação realizado fora do contexto situacional imediato. Em situações desse tipo, o profissional deve ser capaz de refletir na urgência da ação para tomar decisões. Assim como o conhecer-na-ação, a reflexão na ação é um processo que pode ser desenvolvido sem que haja a necessidade de descrição.

c) A reflexão sobre a ação e sobre a reflexão na ação podem ser consideradas como a análise que o profissional realiza a posteriori sobre as características e processos de sua própria ação. Consciente do caráter de reconstrução de sua própria lembrança e da possibilidade de que neste processo se produzam inevitáveis deformações subjetivas, o profissional deverá utilizar métodos, procedimentos e técnicas de contraste intersubjetivo ou dados registrados objetiva e mecanicamente sobre a própria realidade, a fim de minimizar os efeitos deformadores da atividade de reconstrução (PÉREZ GÓMEZ, 1998b).

A reflexão sobre a ação é um componente essencial do processo de aprendizagem permanente que constitui a formação profissional. Em tal processo, abrem-se para a consideração e questionamento, individual ou coletivo, não apenas as características da situação problemática sobre a qual atua o profissional prático, mas também sobre os procedimentos utilizados na fase de diagnóstico e definição do problema, na determinação dos objetivos, na escolha de métodos e na própria intervenção; além disso, a reflexão na ação permite a análise dos esquemas de pensamento, das teorias implícitas, das crenças e das formas de representar a realidade que o profissional utiliza nas situações problemáticas, incertas e conflitantes. Em suma, a reflexão sobre a ação supõe um conhecimento de terceira ordem, que analisa o conhecimento na ação e a reflexão na ação, correlacionando-os com a situação problemática e seu contexto.

A reflexão, portanto, não é meramente um processo psicológico que pode ser estudado apenas do ponto de vista formal, desvinculado do conteúdo, do contexto e das interações. A reflexão implica a imersão consciente do sujeito no mundo de sua experiência, um mundo carregado de conotações, valores, trocas simbólicas, correspondências afetivas, interesses sociais e cenários políticos. Ao contrário de outras formas de conhecimento, a reflexão supõe um sistemático esforço de análise, como a necessidade de elaborar uma proposta totalizadora, que possibilita uma leitura situacional em toda a sua complexidade e orienta a ação. 


\section{Epistemologia da prática e desenvolvimento profissional}

A formação do professor fundada na epistemologia da prática ressignifica a concepção de profisssionalização docente. O ideal do professor tecnólogo, que se apoia nos aportes teóricos oriundos das ciências, que racionaliza a prática sob a orientação de especialistas do planejamento pedagógico e da didática, mostra-se eivado de contradições e limitações próprias da concepção descontextualizada de ciência aplicada. O ideal do professor-pesquisador esbarra nos problemas não resolvidos no âmbito das pesquisas qualitativas, na precariedade da formação do professor em pesquisa social e na divisão estanque das atribuições do pesquisador universitário e do professor da educação básica.

No modelo reflexivo preconizado por Schön, o professor é concebido como um profissional reflexivo, capaz de analisar suas próprias práticas, de resolver problemas, de inventar estratégias. A formação, portanto, deve-se apoiar nas contribuições dos práticos e dos pesquisadores, que também devem conhecer a prática em sua complexidade. A profissionalização é entendida, assim, não como a habilidade de transpor a teoria para a prática, mas como "um processo de racionalização dos conhecimentos postos em ação" (ALTET, 2001, p. 25). Diferente do que acontece nos modelos de formação orientados para a aplicação de teoria, na epistemologia da prática, a profissionalização é entendida como um processo duradouro, que vai se modificando com o passar do tempo, começando na formação inicial e se estendendo por todo o período de efetivo exercício da profissão. Essa compreensão deu origem ao conceito de desenvolvimento profissional:

O desenvolvimento profissional consiste essencialmente na construção de competências e nas transformações identitárias nas situações de trabalho ao longo da carreira. Portanto, o conceito de desenvolvimento profissional remete, antes de tudo, a esse processo individual de aprendizagem de conhecimentos, habilidades atitudes e de sua mobilização em forma de competências para enfrentar, de maneira eficaz, situações profissionais; trata-se, fundamentalmente, do processo do indivíduo que aprende pelo trabalho para seu trabalho! (PAQUAY; VAN NIEUWENHOVEN; WOUTERS, 2012, p. 14). 


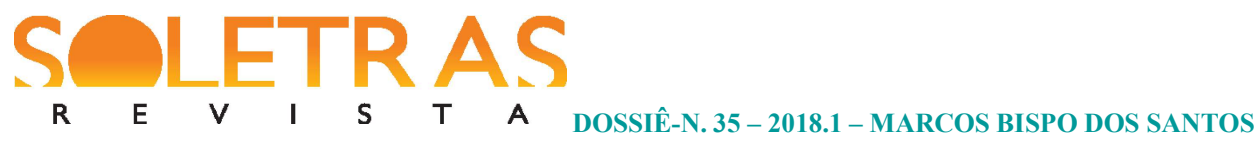

Nos países em que à formação inicial se segue um período de formação do professor iniciante, o desenvolvimento profissional começa após o término desse período (GARCIA, 1999). O processo pode-se dar de maneira autônoma, quando o próprio professor investe em seu crescimento profissional, ou através de projetos institucionais. No Brasil, inexiste o período de iniciação profissional após a graduação, bastando a formação inicial como requisito mínimo para a profissionalização se não de facto, pelo menos de jure. Há quem considere que os cursos de formação continuada se enquadram no conceito de desenvolvimento profissional. García (1999), porém, entende que o conceito pressupõe uma abordagem na formação de professores que valorize o seu caráter contextual, organizacional e sua orientação para a mudança. Essa abordagem apresenta uma forma de implicação a partir de uma perspectiva que supera o caráter tradicionalmente fragmentário e voltado para a transposição de teoria ou aplicação de metodologias didáticas fechadas e diretivas, tal como acontece nas atividades de aperfeiçoamento de professores.

Nesse sentido, considerando os objetivos do Profletras quanto à capacitação dos professores de língua portuguesa, podemos dizer que se trata de um programa de desenvolvimento profissional. Corrobora essa afirmação, o fato de não haver, em sua lista de objetivos, nenhuma referência à formação do pesquisador, como se espera de um MP, uma vez que se trata de uma modalidade de pós-graduação distinta do mestrado acadêmico. No entanto, três fatores têm contribuído para que o trabalho final do programa seja interpretado como resultado de uma pesquisa acadêmica. O primeiro deles diz respeito ao fato de o mestrado acadêmico ser uma referência de pós-graduação de todos os professores do programa. O segundo tem relação com as disputas por prestígio e poder na universidade, que ainda vê os MP como uma modalidade menor. O terceiro se refere ao entendimento do Conselho Gestor, segundo o qual o trabalho final seria uma pesquisa de natureza interpretativa e interventiva. Em função disso, a proposta de intervenção tem sido concebida e/ou executada tendo em vista a aplicação de teorias das ciências da linguagem para resolver problemas pontuais dos alunos. Assim sendo, o que torna a proposta de intervenção um trabalho de pesquisa científica? Como avaliar sua qualidade? Como avaliar as contribuições efetivas do programa ao desenvolvimento profissional dos professores? Diante das limitações da ciência aplicada apresentadas e discutidas aqui, seria ela adequada à

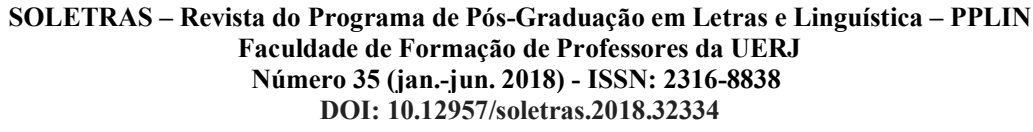




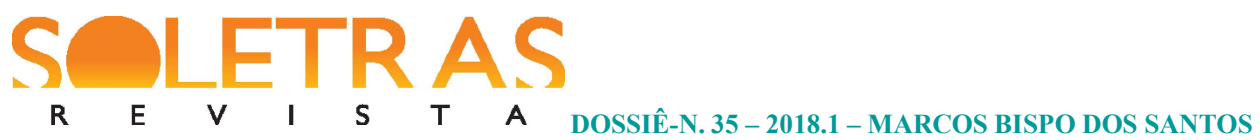

consecução dos objetivos do Profletras? Qual a finalidade da proposta de intervenção no processo de desenvolvimento profissional? Ela deve ser efetivamente aplicada? Qual o papel do orientador nesse processo? Como avaliar o desenvolvimento profissional?

Paquay, Van Nieuwenhoven e Wouters (2012) reconhecem a importância da prática na formação, mas concluem que o desenvolvimento profissional só se realiza pela reflexão sobre a ação. Assim, a aplicação da proposta de intervenção deveria constituir etapa crucial do processo no Profletras. Contudo, cumpre ter clareza de que a prática do professor é um fenômeno complexo que não ocorre simplesmente nas aulas. Começa bem antes, no planejamento das ações. Nesse momento, já é necessário refletir sobre os saberes que serão acionados no próprio ato de planejar e os que serão projetados para as etapas futuras. Como atividade intencional, que envolve aspectos subjetivos ligados à identidade do professor (ou seja, o que é ser professor), e institucional, que engloba fatores objetivos envolvidos na gestão do ensino e da educação, o planejamento é também afetado por representações acerca dos sujeitos da aprendizagem, tendo em vista as concepções de socialização que circulam no espaço escolar. A necessária articulação desses fatores já no ato de planejar afeta a natureza dos objetos de ensino-aprendizagem, os quais não poderão manter suas características de puros objetos científicos quando submetidos aos objetivos sociopolíticos da educação. Essa constatação, ao mesmo tempo em que deslegitima o modelo aplicacionista para fins de desenvolvimento profissional, coloca a questão dos saberes docentes como um objeto central na epistemologia da prática.

Freire (2016) foi um dos primeiros pensadores a valorizar a importância dos saberes docentes, num momento em que florescia o ideal de formação do professor-pesquisador. Sua concepção acerca dos saberes necessários à prática educativa inclui a formação científica, mas não lhe atribui proeminência no conjunto dos saberes que devem compor a competência profissional dos professores, destacando, sobretudo, saberes éticos e praxiológicos ligados a fatores sociopolíticos aos quais a própria ciência deveria estar subordinada.

Tardif (2011) apresenta um enfoque diferente para a compreensão dos saberes que, por não partir de concepções previamente definidas, oferece importantes contribuições para a epistemologia da prática. Uma conclusão a que chega após suas pesquisas, e que deve servir de 


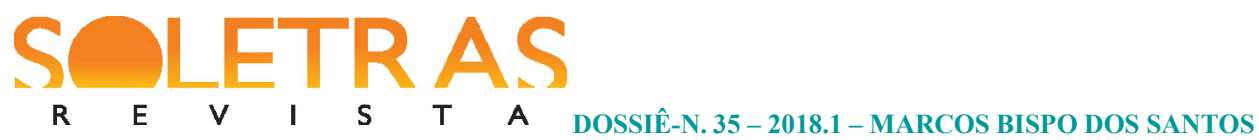

pressuposto básico ou ponto de partida nos projetos de desenvolvimento profissional, é que se torna

[...] impossível compreender a natureza dos professores sem colocá-lo em íntima relação com o que os professores, nos espaços cotidianos de trabalho, são, fazem, pensam e dizem. O saber dos professores é profundamente social e é, ao mesmo tempo, o saber dos atores individuais que o possuem e o incorporam à sua prática profissional para a ela adaptá-lo e para transformá-lo (TARDIF, 2011, p. 15).

Perrenoud (2002) apresenta várias ideias a respeito dos saberes docentes que podem ser tomadas como complementares à posição de Tardif. Uma questão relevante que ele formula é a seguinte: o que acontece com a reflexão quando seu objeto se esconde e a sua própria ação foge ao controle do ator? A pertinência dessa questão estaria no fato de que a ação profissional é composta de um conjunto de saberes e esquemas incorporados, nem sempre conscientes, que Perrenoud, usando uma designação de Piaget, chamou de inconsciente prático; aos esquemas de ação, recorrendo a uma terminologia de Bourdieu, chamou de habitus, um conjunto de disposições interiorizadas, aprendidas por meio da experiência e para a experiência.

A prática reflexiva, portanto, deve partir dos saberes docentes, sem alimentar a ilusão de que se tratam de representações sempre conscientes. Tal condição ressignifica o papel do orientador no Profletras, uma vez que o inconsciente prático não é facilmente acessado pelos práticos. Caberia ao orientador, então, um papel formativo no processo de desenvolvimento profissional do professor em direção às habilidades do saber-analisar suas práticas, aí incluído o habitus. A postura reflexiva assim orientada deve transformar-se num novo habitus, tornando o professor um profissional que submete todos os aspectos que envolvem a sua prática, incluindo suas crenças, ao crivo da racionalização. As transformações da prática profissional a partir da prática reflexiva seriam o critério máximo de avaliação de seu desenvolvimento profissional. 


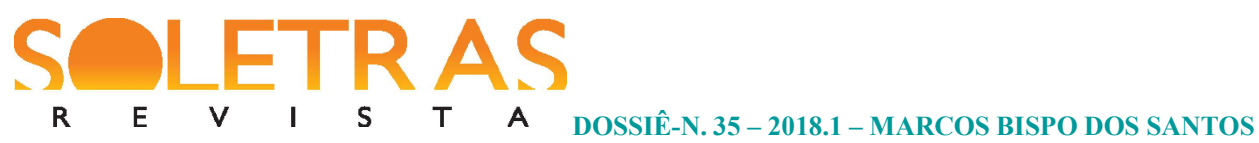

\section{O Mestrado Profissional em Letras no contexto dos MP}

Em abril de 2013, a Capes lançou o Profletras com o propósito de capacitar professores de Língua Portuguesa do Ensino Fundamental, tendo em vista a melhora da qualidade da educação no tocante às competências de leitura e escrita dos estudantes. Os objetivos do Programa ${ }^{2}$ podem ser apresentados com base na tradicional classificação entre gerais e específicos. Na proposta, os gerais expressam o retorno social esperado em decorrência da capacitação dos profissionais:

- Aumento da qualidade do ensino dos alunos do nível fundamental, com vistas a efetivar a desejada curva ascendente quanto à proficiência desses alunos no que se refere às habilidades de leitura e de escrita;

- Declínio das atuais taxas de evasão dos alunos durante o ensino fundamental;

- Multiletramento exigido no mundo globalizado com a presença da internet;

- Desenvolvimento de pedagogias que efetivem a proficiência em letramentos compatível aos nove anos cursados durante o ensino fundamental.

Os específicos referem-se a aspectos pontuais da formação, entendidos como necessários para uma capacitação orientada para o desenvolvimento de práticas de ensino inovadoras:

- Qualificar os mestrandos/docentes para desenvolver múltiplas competências comunicativas dos alunos em ambiente online e offline;

- Instrumentalizar os mestrandos/professores do ensino fundamental de maneira que eles passem a bem conduzir classes heterogêneas, seja do ponto de vista de níveis de competências linguísticas dos alunos, seja no que tange aos quadros de desenvolvimento atípicos que os alunos apresentem;

- Indicar os meios adequados para trabalhar diferentes gêneros discursivos e tipos textuais nas práticas de ensino e da aprendizagem da escrita, da leitura e da produção textual em suportes digitais e não digitais;

- Salientar as funções referenciais e metacognitivas das línguas de forma que os docentes saibam trabalhar peças textuais com traços literais e não literais, distinguindo-as, assim, os planos denotativo e conotativo da linguagem e dos textos;

- Aprofundar os conhecimentos dos docentes no que se refere aos diversos subsistemas fonológico, morfológico, sintático e semântico-pragmático da linguagem;

- Instrumentalizar os docentes de ensino fundamental com objetivo de elaborar material didático inovador que lance mão, quando conveniente e relevante, de recursos tecnológicos modernos à disposição.

\footnotetext{
${ }^{2}$ Disponível em http://capes.gov.br/educacao-a-distancia/profletras. Acesso em 18 out. 2017.
} 


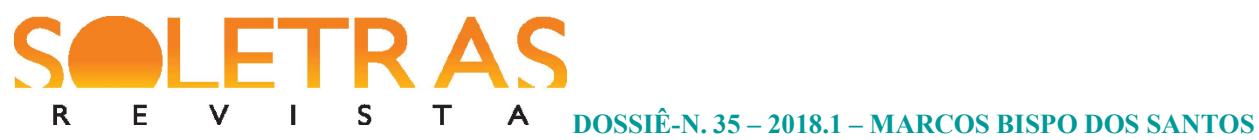

Os objetivos do Programa enfatizam o desenvolvimento de competências diretamente ligadas ao saber-ensinar e, nesse sentido, apontam, em vários aspectos, para um rompimento da relação teoria-prática, bem como da relação entre produção e aplicação do conhecimento.

Emerge da enumeração dos objetivos do Profletras a sensação de que os pólos se inverteram, de modo que as contingências da prática passaram não apenas a determinar o uso da teoria em situações concretas, como também indicam que a própria prática passou a definir os limites das teorias específicas em contextos marcados pela complexidade, a exemplo do ensino de linguagem. Contudo, a qualidade dos objetivos não garante, ipso facto, sua realização. É preciso considerar a qualidade dos meios estabelecidos para sua consecução. No Profletras, os meios se revelam em dois momentos: o do cumprimento da carga horária referente às disciplinas obrigatórias e o da construção e apresentação do produto final ou trabalho de conclusão de curso.

$\mathrm{O}$ alcance do perfil formativo preconizado pelo Profletras exige uma estrutura curricular orientada para o desenvolvimento de competências profissionais. Uma matriz curricular com essas características não prescinde, obviamente, de conhecimentos teóricos, contudo pressupõe que as competências profissionais, o saber-fazer, são processos de tamanha complexidade que jamais poderiam ser satisfatoriamente abordados por um enfoque puramente disciplinar (PERRENOUD, 2013). A decisão aparentemente simples de selecionar um objeto de ensino envolve habilidades de transitar por diferentes campos inter e transdisciplinares: psicopedagógicos (teorias da aprendizagem, metodologias de ensino, planejamento, avaliação etc.), sócio-antropológicos (fatores socioculturais que afetam a escola, professores e alunos), políticos (relações entre sistemas políticos e políticas educacionais, incluindo as finalidades da educação e teorias do currículo), além das disciplinas específicas de atuação do professor. Essas habilidades, porém, não desembocam automaticamente nas competências profissionais.

A rigor, a construção de habilidades de relacionar teorias, conceitos e métodos de diferentes disciplinas tem sido um desafio quase intransponível nos cursos de formação de professores, sobretudo por sua natureza predominantemente disciplinar. Em tal paradigma, os formadores, de modo geral, são especialistas em determinada área de conhecimento e sua prática formativa prioriza a transmissão de saberes teóricos de um campo específico. Quando se

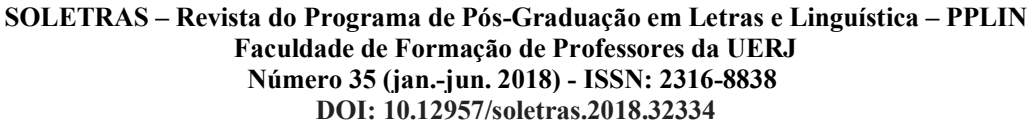




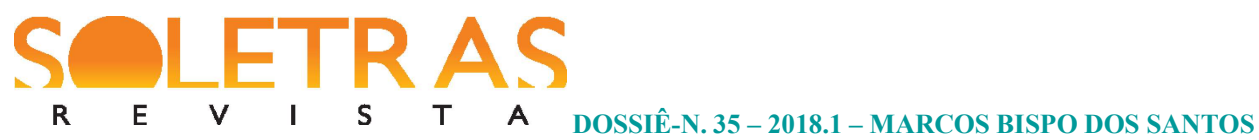

propõem a fazer incursões no terreno da prática profissional, sua condição de especialista continua a determinar suas linhas de atuação. Dificilmente se realiza um trabalho em que um objeto de estudo determinado é situado no contexto profissional, considerado em toda a sua complexidade. Em geral, o máximo que se consegue fazer é uma simulação de como alguns conceitos de uma disciplina poderiam ser abordados no ensino básico, tendo em vista um enfoque aplicacionista $^{3}$, ou seja, aquele orientado pela crença de que é preciso partir da teoria para compreender e transformar a realidade através da transferência direta da teoria pura aos contextos da prática educativa.

Um exame da matriz curricular do Profletras e de seus objetivos aponta para a conclusão de que se trata de um Programa em consonância com a tradição acadêmica que hierarquiza produção teórica e aplicação, portanto, alinhado ao modelo aplicacionista no tratamento da relação teoria-prática. Mesmo com os objetivos voltados para a prática profissional, as disciplinas curriculares, em geral, circunscrevem-se aos domínios da literatura e da linguística. Embora várias delas tragam a palavra "ensino" em sua designação, não há equívoco em afirmar que apenas reforçam o caráter aplicacionista do currículo, uma vez que o termo mencionado tem seu escopo definido pelos termos que mais claramente explicitam a natureza da disciplina, sejam eles gramática (Gramática, variação e ensino), fonologia (Fonologia, variação e ensino), literatura (Literatura e ensino) etc. Assim, o "ensino" que aparece nas designações disciplinares refere-se apenas ao elemento delimitador ou especificador que determina o campo de aplicação dos conhecimentos teóricos.

Em 23 de abril de 2014, o Conselho Gestor do Profletras emitiu um documento em que propõe as diretrizes básicas para o Trabalho de Conclusão Final (TCF), com a ressalva de que considerava prematura a elaboração de uma resolução definitiva sobre o produto final a ser apresentado pelos professores/discentes. No documento, o trabalho é apresentado como uma atividade de pesquisa de natureza interpretativa e interventiva, que deve ter como tema/objeto de investigação um problema da realidade escolar e/ou sala de aula do mestrando, no que concerne

\footnotetext{
${ }^{3} \mathrm{O}$ uso da expressão enfoque aplicacionista, neste texto, se inspira na distinção entre antropologia teórica e antropologia aplicada proposta por Bastide (2009), que atribui a esta última o papel de transferir os conhecimentos da primeira à compreensão e à resolução de problemas práticos da vida sociocultural.
}

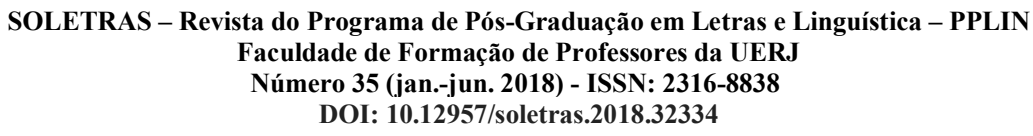




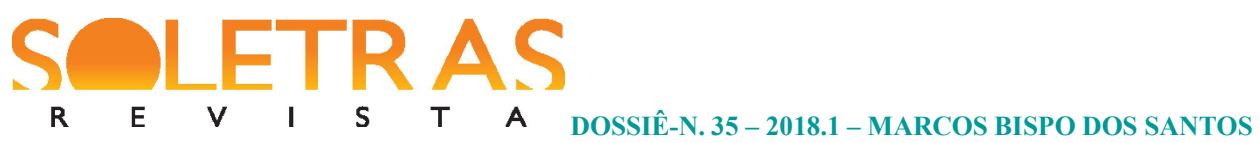

ao ensino e aprendizagem de língua portuguesa no Ensino Fundamental. Estabelece ainda que o TCF deve ser constituído de uma parte teórica e uma prática, podendo ser apresentado de duas formas:

1. Material didático, que tenha suportes como vídeos, software, caderno pedagógico, entre outros. Deverá vir acompanhado de um relatório de pesquisa que tenha, no mínimo, cinquenta páginas, com a seguinte estrutura: I - Elementos pré-textuais; II - Introdução; III - Fundamentação teórica; IV - Metodologia; V - Análise dos dados; VI Bibliografia; VII - Elementos pós-textuais.

2. Dissertação, que deverá ter, no mínimo, cem páginas e apresentar a seguinte estrutura: I Elementos pré-textuais; II - Resumo em português, inglês, ou outra língua estrangeira; III - Sumário; IV - Introdução; V - Fundamentação teórica; VI - Metodologia; VII Análise dos dados; VIII - Proposta para enfrentar o problema; IX - Considerações finais; $\mathrm{X}$ - Bibliografia; XI - Elementos pós-textuais.

Os elementos estruturais do produto final sinalizam uma perspectiva de trabalho fundada nos moldes acadêmicos e aplicacionistas quando propõem a sequência fundamentação teóricametodologia-análise dos dados, uma vez que estabelece a teoria como porto de partida.

No caso da primeira possibilidade de TCF, o material didático, não fica claro como as etapas metodológicas se relacionam como o produto final. Não se sabe se o material didático deverá ser aplicado para, depois, ser elaborado o relatório, ou se haverá uma pesquisa para identificar problemas e, em seguida, a elaboração do material didático, que não seria aplicado. $\mathrm{Ou}$ seja, não fica claro se o material será efetivamente aplicado. Por outro lado, havendo a aplicação do material didático, o que representa essa metodologia, em termos científicos? E a análise de dados? Como avaliar a consecução dos objetivos do Profletras através desse trabalho?

Os mesmos questionamentos se aplicam à segunda possibilidade, a dissertação. A diferença estrutural em relação à primeira opção de produto final é que, após a análise dos dados, segue-se a apresentação da proposta de intervenção. Neste caso, há muita margem para a compreensão de que a aplicação da proposta não seria obrigatória. Porém, para ser considerada uma pesquisa interventiva, é necessário que haja não apenas a aplicação da proposta, mas também a resolução do problema.

Com efeito, as pesquisas interpretativas e interventivas também são praticadas em mestrados e doutorados acadêmicos. Nesse caso, como distinguir o mestrado profissional do

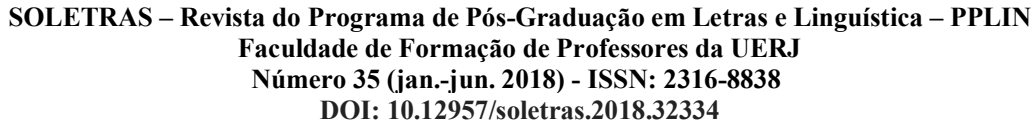




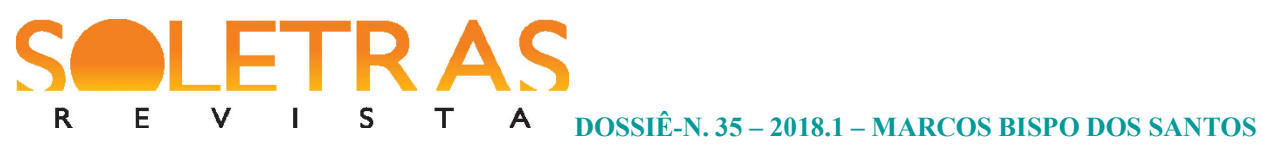

acadêmico? O fato de o tema/objeto ser um problema da realidade escolar, embora desejável num MP, também não é suficiente para caracterizá-lo. Em que medida a resolução de um problema pontual por meio da aplicação de uma proposta de intervenção permite avaliar a capacitação profissional, processo complexo que se desenvolve ao longo da carreira do professor? Não seria esse tipo de pesquisa mais coerente com o tipo de investigação que busca verificar a validade de teorias no campo do ensino?

Diante desses aspectos, é possível afirmar que a proposta de capacitação dos MP, incluindo o Profletras, enquadra-se na perspectiva técnica de formação profissional, aquela que propõe a dar ao ensino um status e um rigor ausentes na prática tradicional, em grande medida determinada pelo mimetismo e pela intuição, ao concebê-lo como uma ciência aplicada. Nesse modelo, o professor é caracterizado como um técnico que domina a aplicação do conhecimento científico produzido por outros e transformado em regras de atuação.

Tal modelo de racionalidade técnica é uma epistemologia da prática derivada da filosofia positivista, construída nas próprias fundações das universidades e dedicada à pesquisa (SCHÖN, 2000). Por meio dela, a atividade profissional é identificada com uma prática instrumental dirigida à solução de problemas por meio da aplicação rigorosa de teorias e técnicas científicas.

Inspirada em modelos de formação próprios da medicina e da engenharia, e tendo em vista a busca por status acadêmico, o currículo normativo de formação docente no âmbito da racionalidade técnica opera mediante uma hierarquia de conhecimentos (SCHÖN, 2000). Em primeiro lugar, aparecem as ciências básicas, que, por apresentarem os fundamentos propriamente científicos da formação, ocupam o maior espaço na estrutura curricular. Em segundo, as ciências aplicadas, que, como a própria designação sugere, aplicam os conhecimentos científicos a determinados contextos. Em terceiro, tem espaço o trabalho com as habilidades técnicas e as práticas cotidianas, que costuma ocorrer após o tempo destinado ao estudo das ciências básicas e aplicadas. Tal hierarquização dos saberes pressupõe que as etapas preliminares ao desenvolvimento de habilidades técnicas de caráter prático fornecem todas as bases conceituais e teórico-metodológicas necessárias para orientar o exercício profissional.

SOLETRAS - Revista do Programa de Pós-Graduação em Letras e Linguística - PPLIN

Faculdade de Formação de Professores da UERJ

Número 35 (jan.-jun. 2018) - ISSN: 2316-8838

DOI: 10.12957/soletras.2018.32334 


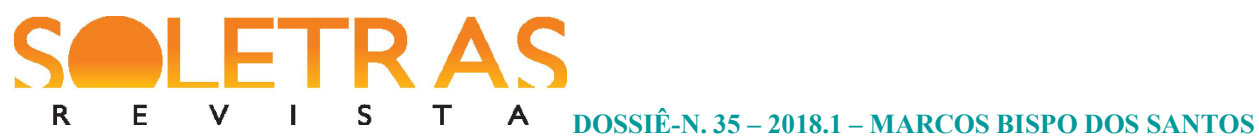

\section{Uma proposta metodológica para o desenvolvimento profissional no Profletras}

Os objetivos de formação profissional do Profletras estão de acordo com o que García (1999) classifica como um processo fundado no tripé planificação-desenvolvimento-avaliação. Trata-se de um processo de aprendizagem mediante o qual o professor deve aprender algo (conhecimentos, competências, disposições, atitudes) num contexto concreto (a escola). Sendo assim, implica a elaboração de um projeto, sua implementação ou desenvolvimento e procedimentos de avaliação.

O desenvolvimento profissional de professores é uma atividade multidimensional, que envolve influências individuais, políticas, sociais, econômicas e profissionais. Por essa razão, como enfatiza García (1999, p. 196), "a planificação, desenvolvimento e avaliação de atividades de desenvolvimento profissional não podem ser realizadas a partir de uma perspectiva meramente técnica, mas será necessário combinar e conjugar tais elementos”.

Com relação aos saberes que devem compor as competências profissionais, Altet (2001) propõe uma tipologia que os distingue entre teóricos e práticos. Os saberes teóricos são da ordem dos declarativos ou conceituais e se dividem em: i) saberes a serem ensinados, que compreendem os disciplinares, os constituídos pelas ciências e os tornados didáticos, com o propósito de permitir aos alunos a aquisição de sabres; ii) saberes para ensinar, abrangendo os conhecimentos pedagógicos sobre a gestão interativa da sala de aula, as didáticas das diferentes disciplinas e os saberes da cultura que os está transmitindo. Os saberes práticos são aqueles decorrentes das experiências cotidianas da profissão, contextualizados e adquiridos em situações de trabalho. Tais saberes se dividem em: i) saberes sobre a prática, isto é, saberes procedimentais acerca do "como fazer"; ii) saberes da prática, oriundos da experiência, produto da ação que, na avaliação do profissional, teve êxito, da práxis e ainda os saberes condicionais (saber quando e onde utilizar determinados saberes).

Quanto ao contexto em que o professor adquire e desenvolve suas competências, e no qual elas ganham sentido pleno, a escola, é fundamental não perder de vista sua função na tarefa de socialização dos indivíduos, por meio de processos de aprendizagem. Perraudeau (2009) relaciona a tipologia dos saberes de Altet com aquilo que os alunos devem desenvolver como indicadores de aprendizagens: os saberes (declarativos ou conceituais), os saberes-fazer

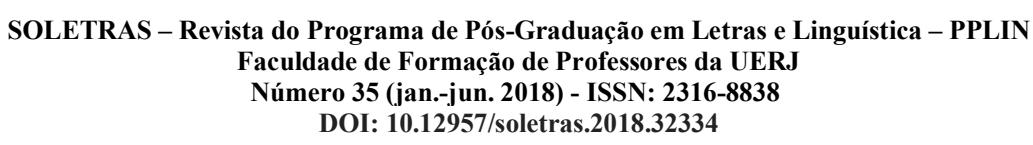






(processuais ou procedimentais) e os saberes-ser (condicionais ou atitudinais). De acordo com Perraudeau, a aprendizagem se estrutura sobre três polos interdependentes: o individual, o social e o contextual.

O polo individual diz respeito ao aluno como sujeito da aprendizagem. São três os componentes desse polo: i) o cognitivo, cujas principais funções são relativas ao desenvolvimento do pensamento, tendo em vista as fases do desenvolvimento psicogenético dos estudantes; ii) o conativo, que se refere à confiança, mais ou menos elevada, que o aluno manifesta, da imagem que tem de si mesmo e que pensa que os outros têm dele, à motivação que influencia seu grau de investimento nas tarefas, ao nível de internalidade em relação ao seu sucesso ou fracasso; iii) o componente afetivo, que diz respeito às formas como o vínculo que o aluno estabelece com a escola, com seus colegas e com seu professor podem constituir uma condição do bom desempenho.

O polo social tem relação com o pertencimento do sujeito a diversos grupos e estruturas nas quais é passível de sofrer a influência de outrem, tais como o meio cultural ao qual o aluno pertence, a família, as representações da escola e do valor da educação na família etc. Perraudeau ressalta que é preciso não analisar tais dados a partir de um olhar determinista.

O polo contextual refere-se ao ambiente da escola. Nesse cenário, Perraudeau (2009, p. 25) assinala a importância da atuação do professor como agente mobilizador das situações de aprendizagem:

\begin{abstract}
A capacidade do professor de mobilizar seus alunos em torno de situações motivadoras e significativas é uma maneira de favorecer a adesão às aprendizagens a importância da singularidade do que se faz em uma aula, e não em outra, traduz-se pelo efeito-professor e pelo efeito-classe [...]. Assim como a apresentação do saber, a qualidade das transposições nas atuações propostas e o grau de dificuldade identificado pelo professor como suportável pelo aluno são elementos importantes [...].
\end{abstract}

Todos os aspectos apresentados nos três polos devem ser considerados tanto em sua singularidade quanto em sua transversalidade e em sua relação constante na prática do professor e, consequentemente, nos projetos de desenvolvimento profissional. De igual modo, tais projetos

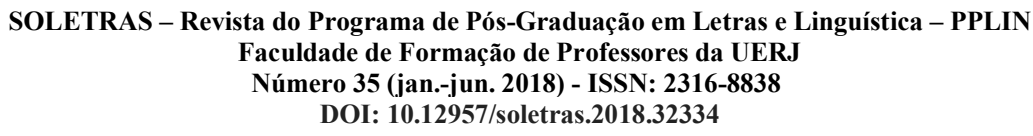




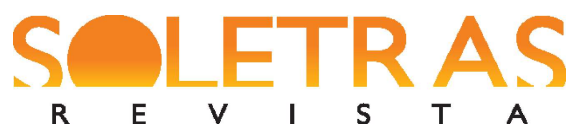

devem envolver processos de investigação e compreensão acerca dos saberes docentes, de acordo com as modalidades propostas por Altet.

A proposta metodológica que será delineada a seguir partirá do pressuposto de que os objetivos do Profletras se voltam para o desenvolvimento profissional do professor de língua portuguesa, entendendo-o como uma condição necessária para o alcance dos objetivos referentes à melhora da qualidade do ensino de linguagem no país. Nesse sentido, a proposta não terá como objetivo a resolução de problemas imediatos dos alunos que serão alvos da proposta de intervenção pedagógica. Não é possível medir o desenvolvimento profissional pelo modelo processo-produto $^{4}$ de ensino-aprendizagem, sobretudo num contexto em que as teorias da aprendizagem e as políticas educacionais definem como objetivos da formação o desenvolvimento de competências e habilidades por parte dos estudantes. Todos os teóricos e profissionais de educação são unânimes em afirmar que não se desenvolvem competências em períodos curtos de trabalho pedagógico, uma vez que elas exigem situações de aprendizagem não apenas diversas, mas que permitam abordagens inter e transdisciplinares, envolvendo, inclusive, reavaliações constantes dos conteúdos disciplinares (PERRENOUD, 2013). Logo, reduzir o trabalho final do Profletras a uma proposta de intervenção de caráter pontual e imediatista representaria uma tentativa de treinamento específico tanto para professores quanto para os alunos, com pouquíssimas contribuições para a compreensão dos professores acerca da complexidade dos problemas que atravessam o ensino de língua portuguesa.

Conforme propõem Sácristan e Pérez Gómez (1998), a compreensão resultante da reflexão sobre a prática é indispensável para a transformação da educação. Por essa razão, no modelo apresentado aqui, a proposta de intervenção corresponde ao recorte da prática em que se desenvolverão as atividades relativamente controladas de ensino, tendo em vista a aplicação da metodologia de desenvolvimento profissional. Um critério norteador do projeto de

\footnotetext{
${ }^{4}$ Pérez Gómez enumera diversas limitações desse modelo de avaliação da qualidade educacional, que reduz o ensino ao comportamento observável do docente, e a aprendizagem ao rendimento acadêmico do estudante unicamente através de resultados de avaliações, sem a devida compreensão dos processos reais de interação. Segundo ele, nesse modelo, "descontextualizam-se as condutas do docente e dos alunos, como se pudessem ser tratadas como comportamentos genéricos universalmente válidos, independentes dos contextos em que se produzem" (1998c, p. 71).
} 


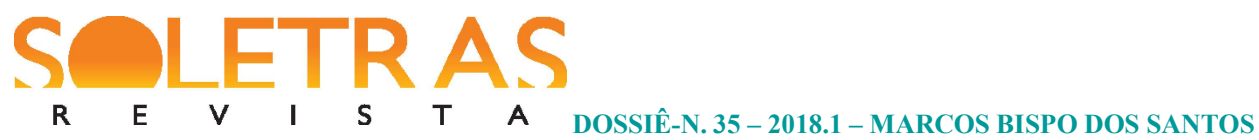

desenvolvimento profisssional será sua estreita vinculação com o contexto real de atuação do professor, como prevê a epistemologia da prática:

Por meio dessa concepção, o trabalho comum tem origem em problemas bastante complexos, permitindo que os profissionais permaneçam em seu terreno, que é o sistema da turma e do estabelecimento de ensino. Ao serem impelidos a realizar um corte muito sutil da realidade e a se interessar por um microprocesso, serão iniciados na pesquisa dos pesquisadores. Não os preparamos para fazer perguntas no contexto de uma prática reflexiva, porque o oficio de professor obriga a considerar todas as dimensões do sistema da turma sem se centralizar em um único aspecto, colocando o resto do mundo entre parênteses. Além disso, essa uma forma de propiciar certa igualdade entre pesquisadores e profissionais: diante da complexidade dos sistemas, todos buscam, improvisam, refletem, enganam-se. Não se segue mais a lógica da transmissão de saberes construídos, mas da exploração, da busca de sentido, da identificação de regularidades (PERRENOUD, 2002, p. 102).

A opção por uma contextualização efetivamente real e não forjada por procedimentos científicos evidencia algumas diferenças entre o projeto de desenvolvimento profissional e o projeto de pesquisa. Em primeiro lugar, enquanto na pesquisa opera-se mediante uma simplificação do objeto, no desenvolvimento profissional é fundamental que sua natureza complexa seja preservada, sob o risco de gerar resultados artificiais que dificilmente poderão ser aclimatados empiricamente ao cotidiano do professor na sala de aula. Em função disso, o projeto de desenvolvimento profissional não pode ser operacionalizado com quantidade de alunos que não correspondam a uma turma, ou ignorar as coerções organizacionais e institucionais que afetam e/ou determinam as formas de atuação do professor, tais como as unidades estruturais da disciplina e a distribuição de sua carga horária semanal, a divisão dos conteúdos em unidades e anos letivos, as especificidades do espaço escolar e dos sujeitos, a elaboração e cumprimento dos planos de curso e de aulas, as condições de utilização de novas tecnologias, o cumprimento dos objetivos determinados nas políticas educacionais que norteiam o funcionamento da escola, dentre outros.

Outro aspecto que diferencia a pesquisa e o desenvolvimento profissional diz respeito ao papel dos saberes na relação, normalmente hierárquica, entre pesquisador e professor. Como a 


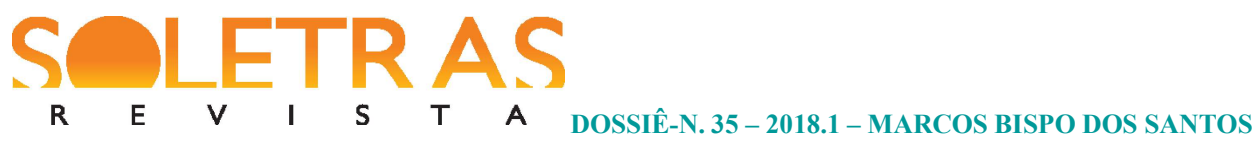

epistemologia da prática rompe com a perspectiva técnica de formação docente, não é seu objetivo partir de conhecimentos estabelecidos como verdadeiros do ponto de vista científico para explicar a realidade, mas problematizá-la explorando os vazios que se instalam entre a teoria científica simplificadora do real e a prática, marcada pela complexidade, com o intuito de elaborar representações globalizantes que possibilitem sua transformação. Como diz Charlot (2012, p. 104), “a pesquisa faz análise, é analítica; o ensino visa a metas, objetivos; o ensino tem uma dimensão axiológica, uma dimensão política". As metas em educação são alcançadas mediante a utilização de estratégias, sobretudo, didáticas e pedagógicas que exigem do professor, não raras vezes, a capacidade de transformar conhecimentos de diversas naturezas em conhecimentos didáticos. Essas especificidades da relação dos professores com os saberes colocam muitos desafios ao formador de professores, exigindo que ele se interrogue sobre seus próprios saberes e que se coloque na posição de alguém que não vai apenas ensinar, mas também aprender. Assim, uma importante competência do professor reflexivo é a capacidade de problematização da realidade e da prática.

Explicitadas algumas diferenças entre o projeto de pesquisa e o projeto de desenvolvimento profissional e, uma vez definido que o alvo deste último, no Profletras, não é, imediatamente, o aluno, mas o professor, é preciso definir qual o objetivo da formação e os meios adequados para alcançá-lo. Já se asseverou aqui que o desenvolvimento profissional, no contexto da epistemologia da prática, tem como objetivo a formação do professor reflexivo. Esse processo não invalida a importância da pesquisa nem dos métodos e teorias científicas, mas submete-os a outra forma de racionalidade, orientada para a profissionalização. Além disso, a noção de pesquisa não se confunde com a pesquisa científica, abrangendo a postura investigativa que todo professor deve adotar diante das contingências e coerções institucionais e socioculturais que perpassam o ensino. Com base nesses pressupostos, o modelo de formação prevê três grandes unidades estruturais em torno das quais se desenvolverão as diversas atividades que comporão o processo de desenvolvimento profissional: a análise situacional, o planejamento e a implementação da proposta de intervenção, além da avaliação. 


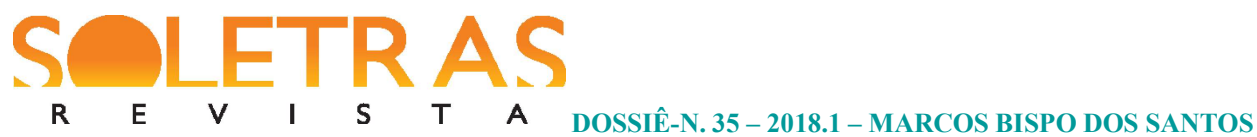

\section{A análise situacional}

A análise situacional tem a finalidade de permitir um diagnóstico do estado profissional do professor, de maneira que seja possível identificar e selecionar necessidades formativas que serão objetos do projeto de desenvolvimento. Nessa etapa, a coleta de dados deverá ser conduzida pelo orientador-formador, utilizando métodos, preferencialmente qualitativos, para identificar os saberes teóricos (a serem ensinados e para ensinar) e práticos (sobre a prática e da prática). $\mathrm{O}$ orientador pode utilizar a etnografia, a narrativa autobiográfica, a entrevista narrativa, questionários, entrevista semiestruturada, a observação participante, filmagem das práticas, análise de documentos (atividades, avaliações, planos de cursos e de aulas elaborados pelo professor), dentre outros. Outra etapa importante da investigação referente aos saberes docentes diz respeito à sua capacidade de elaborar materiais didáticos. Como a proposta de intervenção também prevê a elaboração de uma atividade diagnóstica como parte da análise situacional que o professor deve fazer em relação à turma, é recomendável que a elaboração dessa atividade seja também um elemento do diagnóstico do professor. Através dela será possível avaliar importantes aspectos do habitus profissional. Essas informações serão importantes marcos referenciais nos processos de reflexão que ocorrerão durante as atividades de planificação, implementação e avaliação da proposta de intervenção. Ao final dessa etapa, o orientador deve ter respostas iniciais para as questões relativas ao perfil profissional do professor, iniciando por sua formação inicial e continuada até o seu estado atual.

\section{A proposta de intervenção}

Nessa etapa, o professor deverá colocar em ação, de maneira constante e interdependente, as três artes propostas por Schön: a arte da sistematização de problemas, a arte da implementação e a arte da improvisação. É importante ressaltar, mais uma vez, que a aplicação da proposta deve levar em conta a complexidade do contexto escolar e da sala de aula, evitando criar situações artificialmente construídas especificamente para garantir a realização de um trabalho de pósgraduação. Assim, é preciso considerar que o trabalho deve:

- ser desenvolvido em, pelo menos, uma turma e incluir todos os alunos no processo;

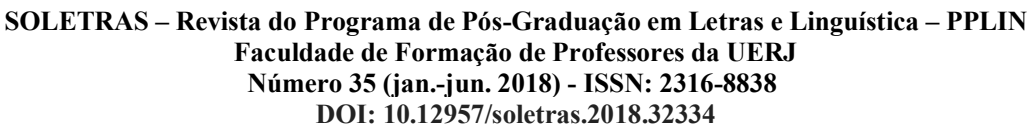




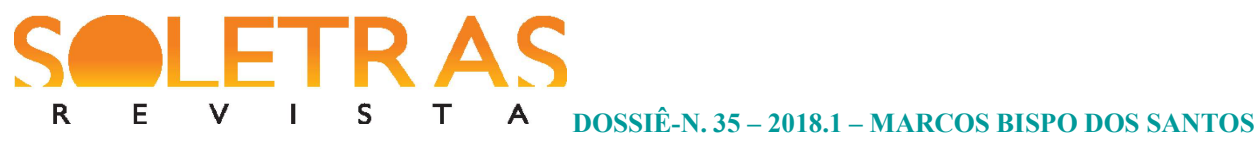

- cuidar para que a aplicação da proposta de intervenção não represente a supressão dos demais conteúdos que compõem o plano de curso da turma em questão;

- evitar a criação de espaços e momentos (turno oposto) que não fazem parte daqueles já definidos pela escola, conforme a carga horária do professor, tendo em vista, exclusivamente, os objetivos da aplicação da proposta;

- voltar-se para a construção de aprendizagens dos alunos e não para o simples cumprimento do plano da proposta;

- envolver processos de avaliação quantitativa e qualitativa.

A proposta de intervenção deve ser o resultado de um estudo da realidade da turma, considerando os três polos que compõem o processo educativo, conforme aponta Perraudeau (o individual, o social e o contextual). Trata-se de uma análise situacional que o professor deve realizar em relação aos alunos, através de métodos de coleta de dados que envolvem instrumentos próprios da pesquisa qualitativa e da avaliação diagnóstica em educação. Aqui a utilização de métodos tidos como científicos, tais como a etnografia, entrevistas e questionários, está voltada para fins estritamente pedagógicos, uma vez que o conhecimento dos estudantes vai permitir a escolha dos conteúdos e das estratégias metodológicas mais adequadas aos objetivos do ensino. A aplicação dos instrumentos deve permitir a coleta de dados socioeconômicos e psicopedagógicos a respeito dos estudantes, bem como possibilitar um diagnóstico sobre seus saberes em relação ao tema da proposta de intervenção ${ }^{5}$.

A avaliação diagnóstica é uma etapa necessária de todo projeto de intervenção orientado para a mudança de uma realidade ou estado de coisas. Sua finalidade básica é fornecer os dados que vão permitir a descrição dessa realidade, passo fundamental para que seja possível decidir sobre as necessidades de intervenção e os aspectos sobre os quais ela deve incidir. Na medicina, por exemplo, os exames solicitados pelo médico cumprem a função de coletar dados sobre a saúde dos pacientes para subsidiar as decisões posteriores do profissional. McWilliams (2014),

\footnotetext{
${ }^{5} \mathrm{O}$ levantamento dos saberes dos estudantes acerca do tema da proposta de intervenção é uma questão complexa que precisa ser cuidadosamente tratada pelo professor, em parceria com seu orientador. Quando se opta por abordar um tema familiar aos estudantes, é possível que o diagnóstico apresente questões diretamente ligadas ao tema, no sentido de identificar os saberes dos alunos acerca dele. Porém, quando o tema é uma novidade para os alunos e/ou para os professores, é preciso que o diagnóstico busque identificar se os alunos possuem ou não saberes considerados básicos para a construção das novas aprendizagens que constituem os objetivos do projeto de intervenção.
} 


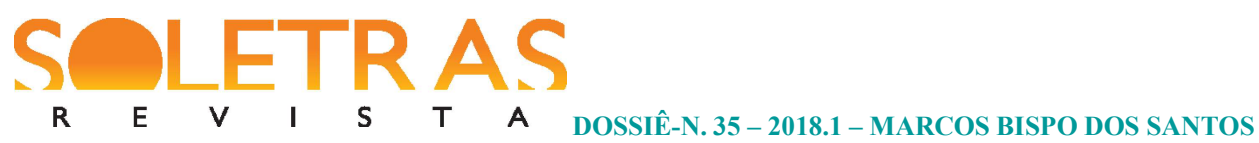

no âmbito da clínica psicanalítica, assinala que um bom diagnóstico é um elemento fundamental para a definição do planejamento da terapia. Sánchez-Cano e Bonals (2008, p. 17) ressaltam o papel da avaliação diagnóstica para as intervenções no campo da psicopedagogia:

A avaliação psicopedagógica normalmente se inicia com a detecção de uma necessidade. Concretiza-se em uma demanda de intervenção profissional com a finalidade de buscar melhorias na situação colocada. Inicia um processo compartilhado de coleta e análise de informações, formulação de hipóteses e tomada de decisões.

Thiollent (2011, p. 56) situa o diagnóstico na fase exploratória da pesquisa-ação como etapa necessária para a avaliação prospectiva da viabilidade de uma intervenção, que caracteriza a natureza da pesquisa: "A fase exploratória consiste em descobrir o campo de pesquisa, os interessados e suas expectativas e estabelecer um primeiro levantamento (ou "diagnóstico") da situação, dos problemas prioritários e de eventuais ações".

No contexto pedagógico, aquele mais diretamente ligado ao cotidiano do professor, Luckesi (2011) defende que o ato educativo, por natureza um processo de intervenção, deve-se iniciar sempre pela avaliação diagnóstica, considerando que: "O desempenho dos estudantes, ao responderem aos instrumentos ou ao agirem, permite-nos saber se aprenderam. Permite uma descrição do seu desempenho e sugere, se o desejarmos, a busca da razão pela qual alguma aprendizagem não foi realizada" (p. 280).

O trabalho desenvolvido nessa etapa deve conscientizar o professor da necessidade de conhecer a situação inicial dos alunos antes de planejar o trabalho a ser desenvolvido ${ }^{6}$, assim como capacitá-lo para a elaboração dos instrumentos de coletas e também para a análise dos dados. Além disso, é possível identificar tanto os saberes teóricos e práticos quanto o habitus que

\footnotetext{
${ }^{6}$ Normalmente o planejamento é feito nas escolas antes que os alunos sejam conhecidos. Em consequência disso, o trabalho desenvolvido está mais voltado para o cumprimento do conteúdo programático do que para a construção das aprendizagens. A formação reflexiva de professores buscada no projeto de desenvolvimento profissional deve fazê-los perceber os equívocos desse procedimento ao problematizar, implementar e avaliar o planejamento das ações a partir da investigação da realidade, considerando os polos da aprendizagem apresentados por Perraudeau (2009).
}

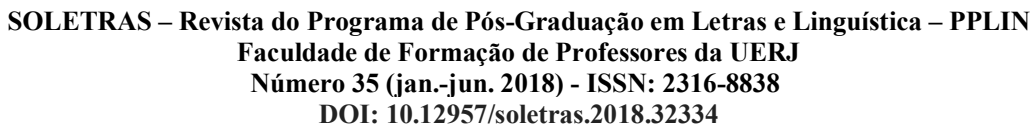




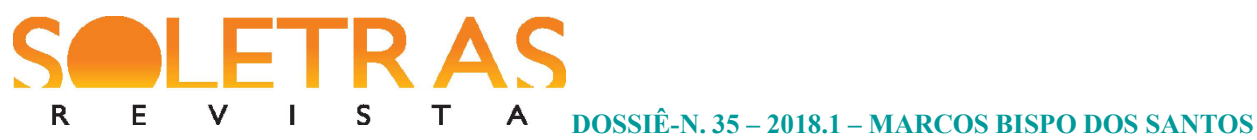

o professor utiliza em sua prática, dados importantes para compor a descrição do perfil profissional do docente e para orientar a elaboração do projeto voltado para seu desenvolvimento. Para efeitos de comparação e avaliação do trabalho desenvolvido, será importante uma análise quantitativa e qualitativa da avaliação diagnóstica aplicada aos alunos, cujos resultados deverão ser confrontados com uma avaliação a ser realizada no final da aplicação da proposta de intervenção. A partir do levantamento das necessidades de aprendizagem dos estudantes, passa-se para as demais etapas da proposta de intervenção:

a) planejamento da ação: consiste na elaboração do plano geral de trabalho com base nos dados extraídos de todos os instrumentos utilizados para a realização da análise situacional. Deve incluir as etapas da intervenção, o período total da proposta e o de cada etapa, os objetivos, conteúdos e as concepções de ensino, aprendizagem e avaliação que vão orientar o trabalho. No planejamento da proposta, o professor deve colocar em prática o conhecimento na ação e a reflexão sobre a ação. Para isso, deve confrontar a forma como normalmente executava essa tarefa com a forma como a executa no processo de desenvolvimento profissional, influenciado por novos conhecimentos teóricos da área de conhecimentos específicos da disciplina e pedagógicos;

b) implementação do plano: elaboração dos planos de aulas diários contendo: data, carga horária, objetivos, conteúdos, estratégias pedagógicas, recursos pedagógicos e forma da avaliação. Nessa etapa, o professor colocará em prática o conhecimento na ação e a reflexão na ação. A depender da complexidade da proposta, é recomendável dividi-la em etapas, desde que seja possível definir unidades de um todo que precisam ser tratadas didática e pedagogicamente de maneira particularizada, tendo em vista uma síntese posterior. Após cada aula, deve ter início a reflexão sobre a ação para fins de registro e construção do relatório final. O professor deverá registrar tanto a realização das aulas quanto as reflexões sobre elas em diários de campo, além de reflexões sobre todo o trabalho desenvolvido em cada etapa. Para a reflexão sobre a ação, o professor deverá recorrer a informações com as quais teve contato no processo de formação e investigação teórica para avaliar a necessidade de promover modificações em sua prática. Dessa forma, o conhecimento na ação poderá ser transformado pela apropriação de novos saberes.

c) Análise e discussão dos resultados: se a etapa de implementação da ação tinha o caráter pontual e se referia ao que acontecia em cada aula, de maneira mais imediata, ou tendo em vista a sequenciação das atividades nas aulas e etapas, aqui a reflexão sobre a ação deverá abranger a dimensão global da implementação da proposta de intervenção, com o objetivo de avaliar os resultados obtidos. Neste momento, devem-se confrontar os dados da avaliação inicial com os da final. A análise não deve levar em conta apenas os 


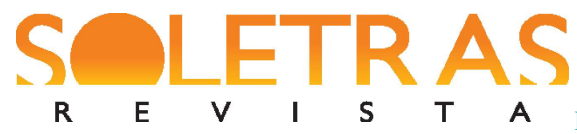

resultados quantitativos, mas refletir sobre como o processo possibilitou o resultado alcançado, ou seja, deve incluir uma análise qualitativa.

\section{Avaliação}

O profissional reflexivo deve ser capaz de entender que os projetos educacionais são sempre situados. As práticas de sucesso não são facilmente transferíveis para outros contextos. Diante disso, a reflexão sobre a reflexão na ação deve proporcionar ao professor a elaboração de princípios gerais sobre sua prática sempre abertos aos condicionantes contextuais em que ela se desenvolve. Nesta etapa da pesquisa, o professor deve refletir sobre todo o processo desenvolvido nas etapas anteriores, avaliar sua relação com o habitus da profissão, consolidar suas aprendizagens e apontar as contribuições do trabalho realizado para seu desenvolvimento profissional.

A execução dessas etapas não garante, ipso facto, que o projeto de desenvolvimento profissional logre êxito. Para que isso seja possível, faz-se necessária a utilização de estratégias maiêuticas por parte do orientador-formador, com a finalidade de conduzir o professor à elaboração de problematizações e reflexões sobre sua prática. Nesse sentido, se concebemos o desenvolvimento profissional como um processo ininterrupto na trajetória do professor, é fundamental que se tenha clareza acerca de seu objetivo principal: munir o professor dos princípios teórico-metodológicos gerais que o habilitem a conduzir sua própria trajetória de prático reflexivo. É preciso, portanto, que o processo resulte em aprendizagens de princípios transferíveis à compreensão e possíveis transformações de outras situações e não, simplesmente, em produtos acabados que,supostamente, estariam em condições de reprodução pelo próprio docente ou por outros professores, independente de eles terem percorrido o caminho formativo que o produziu,ou das especificidades dos sujeitos e dos contextos nos quais tais materiais seriam, eventualmente, aplicados. Os livros didáticos utilizados nas escolas são bons exemplos de material produzido para sujeitos idealizados.

De modo análogo, a simples aplicação de uma proposta de intervenção destinada a confrontar problemas pontuais dos alunos converte o que deveria ser um processo formativo voltado para o professor num mero exercício de aplicação de planejamento pedagógico, sem 


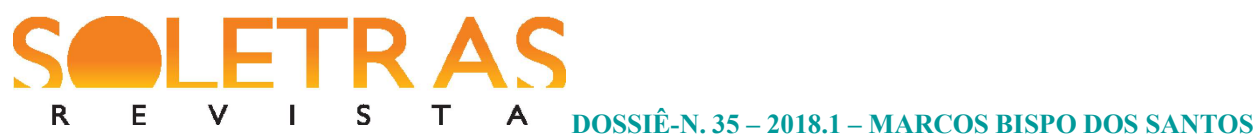

maiores consequências para a (re)construção identitária do profissional. Como bem observa Perrenoud (2002, p. 44):

\begin{abstract}
Um profissional reflexivo não se limita ao que aprendeu no período de formação inicial, nem ao que descobriu em seus primeiros anos de prática. Ele reexamina constantemente seus objetivos, seus procedimentos, suas evidências e seus saberes. Ingressa em um ciclo permanente de aperfeiçoamento, já que teoriza sua própria prática, seja consigo mesmo, seja com uma equipe pedagógica. $\mathrm{O}$ professor faz perguntas, tenta compreender seus fracassos, projeta-se no futuro; decide proceder de forma diferente quando ocorrer uma situação semelhante ou quando o ano seguinte se iniciar, estabelece objetivos mais claros, explicita suas expectativas e seus procedimentos. A prática reflexiva é um trabalho que, para se tornar regular, exige uma postura e uma identidade particulares.
\end{abstract}

\title{
Considerações finais
}

Os MP se caracterizam pelo objetivo de capacitação profissional mediante a aplicação de teorias e métodos científicos às situações de trabalho. Tal modelo de formação pode aplicar-se a contextos em que a transposição da teoria gera produtos ou um conjunto de procedimentos, em geral padronizadas. A educação, pelo contrário, jamais será uma prática controlada pela teoria científica ou até mesmo por conhecimentos advindos das experiências pregressas, sejam do próprio professor ou de outros, porque tanto os sujeitos quanto os contextos, incluindo as relações entre eles, jamais serão totalmente repetíveis. Tais fatores inundam a prática educativa de zonas de indefinição, de vazios entre a teoria e a prática, nas quais será preciso, muitas vezes, agir na urgência e decidir na incerteza. Por essa razão, um MP voltado para a área de educação não pode contentar-se com produtos finais como a elaboração de material didático ou uma dissertação resultante de pesquisa. Se assim for, será muito difícil fugir ao risco de funcionar, prioritariamente, como uma instância destinada a conceder diplomas de pós-graduação.

De modo paradoxal, os objetivos do Profletras estão voltados para o desenvolvimento profissional dos professores, enquanto as modalidades de trabalho final propostas, ainda que em caráter provisório, perseguem produtos pontuais que, conforme os pressupostos da epistemologia da prática, pouco informam sobre a qualificação efetiva dos professores, sobretudo quando tais

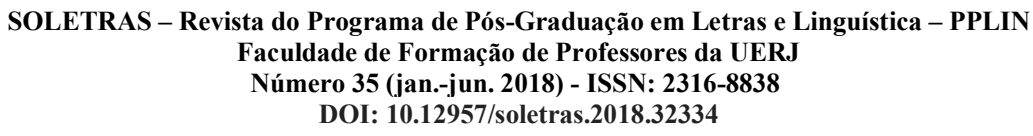




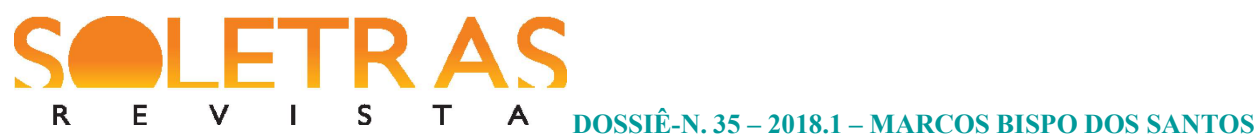

produtos desconsideram as especificidades e complexidade do contexto escolar, evidenciando maior preocupação em demonstrar o sucesso de uma proposta concebida de acordo com o modelo aplicacionista.

No modelo teórico-metodológico de desenvolvimento profissional proposto neste trabalho, a formação do prático reflexivo deve ser o grande objetivo do Profletras. Através dele, será possível, pelo menos, minimizar os efeitos de um utilitarismo individualista por meio do qual o professor poderia motivar-se para cursar o mestrado profissional apenas como uma forma de garantir retorno financeiro, visto que torna evidente o fato de que a responsabilidade epistêmica é um dos componentes da ética profissional:

\footnotetext{
Uma prática reflexiva não é apenas uma competência a serviço dos interesses do professor, é uma expressão da consciência profissional. Os professores que só refletem por necessidade e que abandonam o processo de questionamento quando se sentem seguros não são profissionais reflexivos.

[...]

A preguiça intelectual inibe a prática reflexiva. Esta última representa um trabalho do espírito, tanto na essência da ação quanto no momento posterior a ela. Ainda que esse trabalho seja livremente escolhido e vivenciado de modo construtivo, ele exige energia e obstinação (PERRENOUD, 2002, p. 50 e 52).
}

Os elementos que estruturam a metodologia do projeto de desenvolvimento proposto aqui permitem também visualizar uma estrutura do trabalho final capaz de explicitar o processo de formação do prático reflexivo. Independente da designação genérica que esse texto possa ter, importa mais a definição de sua natureza, caracterizada não como uma descrição de pesquisa, mas como um relato de experiência de formação, no qual estariam presentes teorias e técnicas de pesquisa científicas, teorias e técnicas didáticas e pedagógicas e teorias e técnicas de formação profissional.

\section{Referências bibliográficas}

ALTET, M. As competências do professor profissional: entre conhecimentos, esquemas de ação e adaptação, saber analisar. In: PAQUAY, L.; PERRENOUD, P.; ALTET, M. CHARLIER, E. (Org.). Formando professores profissionais: quais estratégias? Quais competências? 2. ed. Trad. Fátima Murad; Eunice Gruman. Porto Alegre: Artmed, 2001, p. 23-35.

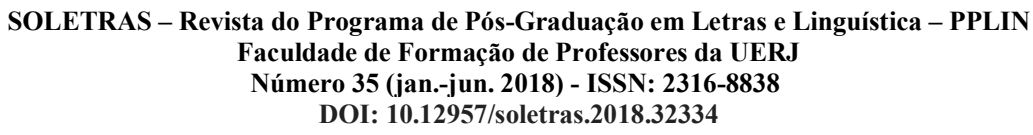




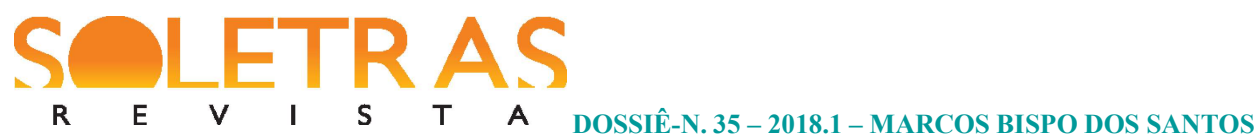

BASTIDE, R. Antropologia Aplicada. E. Ed. Trad. Maria Lúcia Pereira e J. Guinsburg. São Paulo: Perspectiva, 2009.

BRASIL. Ministério da Educação. Portaria Normativa No - 7, de 22 de junho de 2009. Dispõe sobre o mestrado profissional no âmbito da Fundação Coordenação de Aperfeiçoamento de Pessoal de Nível Superior - CAPES.

CHARLOT, B. Formação de professores: a pesquisa e a política educacional. In: PIMENTA, S. G.; GHEDIN, E. Professor reflexivo no Brasil: gênese e crítica de um conceito. 7. ed. São Paulo: Cortez, 2012, p. 103-126.

FREIRE, P. Pedagogia da autonomia: saberes necessários à prática educativa. 53. ed. Rio de Janeiro: Paz e Terra, 2016.

GARCÍA, C. M. Formação de professores para uma mudança educativa. Trad. Isabel Narciso. Porto, Portugal: Porto Editora, 1999.

LUCKESI, C. C. Avaliação da aprendizagem: componente do ato pedagógico. São Paulo: Cortez, 2011.

McWILLIAMS, N. Diagnóstico psicanalítico: entendendo a estrutura da personalidade humana. Trad. Gabriela WondracekLinck. 2. ed. Porto Alegre: Artmed, 2014.

PAQUAY, L.; VAN NIEUWENHOVEN, C.; WOUTERS, P. (Org.)A avaliação como ferramenta de desenvolvimento profissional de educadores. Trad. Fátima Murad. Porto Alegre: Penso, 2012.

PÉREZ GÓMEZ, A. I. Os processos de ensino-aprendizagem: análise didática das principais teorias da aprendizagem. In: SACRISTÁN, J. G.; GÓMEZ, A. I. P. Compreender e transformar o ensino. 4. ed. Trad.: Ernani F. da Fonseca Rosa. Porto Alegre: Artmed, 1998a, p. 27-52.

A função e formação do professor/a no ensino para a compreensão: diferentes perspectivas. In: SACRISTÁN, J. G.; GÓMEZ, A. I. P. Compreender e transformar o ensino. 4. ed. Trad.: Ernani F. da Fonseca Rosa. Porto Alegre: Artmed, 1998b, p. 353-380.

. Ensino para a compreensão. In: SACRISTÁN, J. G.; GÓMEZ, A. I. P. Compreender e transformar o ensino. 4. ed. Trad.: Ernani F. da Fonseca Rosa. Porto Alegre: Artmed, 1998b, p. 67-97.

PERRAUDEAU. M. Estratégias de aprendizagem: como acompanhar os alunos na aquisição de saberes. Trad. Sandra Loguercio. Porto Alegre: Artmed, 2009.

SOLETRAS - Revista do Programa de Pós-Graduação em Letras e Linguística - PPLIN

Faculdade de Formação de Professores da UERJ

Número 35 (jan.-jun. 2018) - ISSN: 2316-8838

DOI: 10.12957/soletras.2018.32334 


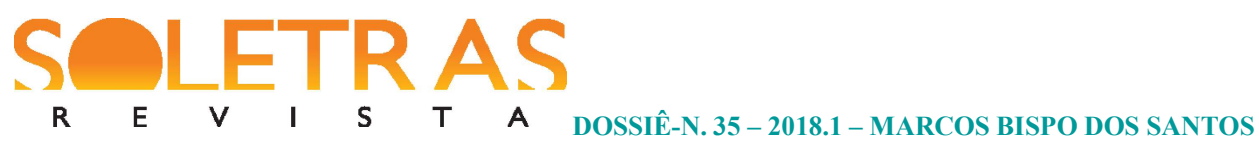

PERRENOUD, P.A prática reflexiva no oficio de professor: profissionalização e razão pedagógica. Trad. Cláudia Schilling. Porto Alegre: Artmed, 2002.

. Desenvolver competências ou ensinar saberes? A escola que prepara para a vida. Trad. Laura Solange Pereira. Porto Alegre: Penso, 2013.

SACRISTÁN, J. G.; GÓMEZ, A. I. P. Compreender e transformar o ensino. 4. ed. Trad.: Ernani F. da Fonseca Rosa. Porto Alegre: Artmed, 1998.

SÁNCHEZ-CANO, M.; BONALS, J. Avaliação psicopedagógica. Trad. Fátima Murad. Porto Alegre: Artmed, 2008.

SCHÖN, D. A. Educando o Profissional Reflexivo: um novo design para o ensino e a aprendizagem. Trad. Roberto Cataldo Costa. Porto Alegre: Artmed, 2000.

TARDIF, M. Saberes docentes e formação profissional. 12. ed. Trad.: Francisco Pereira. Petrópolis, RJ: Vozes, 2011.

THIOLLENT, M. Metodologia da pesquisa-ação. 18ª ed. São Paulo: Cortez, 2011.

\title{
Epistemology of practice and professional development in Professional Master's Program in Language and Literature
}

\begin{abstract}
The Professional Master's Program in Language and Literature (Profletras) began in 2013 as a result of the effort to expand the professional master's degree modality which was conceived in Brazil in 1965, as stated in Opinion 977/65 of the Federal Council on Education. This article questions the adequacy of applied research based on the transposition of theories to promote teachers' professional development, according to the objectives of the program. Departing from the proposal of professional training based on the Epistemology of Practice elaborated by Schön (2000) and developed by several authors such as García (1999), Perrenoud (2008), Paquay et al. (2012), Tardif (2011) and others, this article presents a professional training model for a reflexive teacher, which is understood here as more coherent to the objectives of the Program.
\end{abstract}

Keywords: Professional Master's Program in Language and Literature. Professional development. Teacher-researcher.

Recebido em 20 de janeiro de 2018.

Aprovado em 09 de maio de 2018.

SOLETRAS - Revista do Programa de Pós-Graduação em Letras e Linguística - PPLIN

Faculdade de Formação de Professores da UERJ

Número 35 (jan.-jun. 2018) - ISSN: 2316-8838

DOI: 10.12957/soletras.2018.32334 